\title{
Citizen Lawsuit in Environmental Cases
}

\author{
Abdul Fatah \\ University of Muhammadiyah Sidoarjo, Indonesia \\ efat77@gmail.com
}

\begin{abstract}
The citizen law suit is one of the effective alternatives for the environmental law enforcement. The citizen lawsuit in environmental disputes has been regulated in the PPLH Law specifically Article 91 paragraph (1) and the Chief Justice of the Indonesian Supreme Court Number 36/KMA/SK/II/2013 concerning the Implementation of Guidelines for Handling Environmental Cases. However, there are no specific rules governing citizen lawsuits in Indonesia because it's not widely known in the Indonesian legal system. This paper argues that there are three main constraints to the practice of citizen lawsuits in environmental cases, namely: (1) the absence of legal rules that specifically regulate citizen lawsuits, especially the reading mechanism; (2) lack of understanding of law enforcement officials (especially judges) regarding citizen lawsuits; and (3) lack of environmental-certified judges in Indonesia, especially in regions.
\end{abstract}

KEYWORDS: Citizen Lawsuit, Environment, Government.

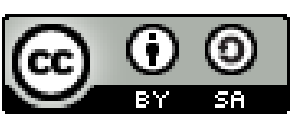

Copyright $\odot 2019$ by Author(s)

This work is licensed under a Creative Commons Attribution-ShareAlike 4.0 International License. All writings published in this journal are personal views of the authors and do not represent the views of this journal and the author's affiliated institutions.

\section{HOW TO CITE:}

Fatah, Abdul. "Citizen Lawsuit in Environmental Cases" (2019) 6:2 Lentera Hukum 289-308.

Submitted: February 02, 2019 Revised: May 09, 2019 Accepted: May 20, 2019 


\section{INTRODUCTION}

A good and healthy environment is the constitutional right of every citizen. The guarantee and protection of a healthy and good environment in Indonesia is regulated in the provisions of Article 28H paragraph (1) and Article 33 paragraph (4) of the 1945 Constitution of Indonesia (UUD 1945). Article 28H paragraph (l) of the 1945 Constitution states that "everyone has the right to live in physical and spiritual prosperity, to live and obtain a good and healthy environment and the right to receive health services." Whereas Article 33 paragraph (4) of the 1945 Constitution states that "the national economy is organized based on economic democracy with the principle of togetherness, efficiency with justice, sustainability, environmentally oriented, independence, and by maintaining a balance of progress and unity of the national economy." The two articles provide the basis for constitutional arguments for the fulfillment of a good and healthy environment for every citizen of Indonesia.

The inclusion of environmental issues in the constitution provides an acknowledgment of environmental protection and becomes a new concept: agreen constitution. This concept was popularized by Jimly Asshiddiqie. ${ }^{1}$ Principally, green constitution tries to elevate the degree of environmental protection norms to the level of the constitution. Thus, the importance of the principles of environmentally sustainable development and protection of the environment has a strong basis in legislation. On that basis, green constitution then introduces the terminology and concept of ecocracy, which emphasizes the importance of environmental sovereignty. ${ }^{2}$ Besides being placed in the state constitution, the issue of protection and management of a good and healthy environment in Indonesia technically and operationally is regulated in Law No. 32 of 2009 concerning Environmental Protection and Management (PPLH Law). The PPLH Law becomes an environmental law in Indonesia which functions as social control and a tool of social engineering. ${ }^{3}$

Current environmental violations and disputes in Indonesia are still quite high in frequency even though extant environmental norms are provide adequate prevention. In the last ten years there have been several cases of environmental disputes in Indonesia. These cases include the Gemulo spring dispute in Batu City, East Java. The dispute between the business actor and the residents occurred because local government permitted a hotel permission to operate above the spring. The case was presented at the Malang District Court, then an appeal was made at the Surabaya High Court, and the case was finally decided by the Supreme Court of the Republic of Indonesia in the examination of the cassation level. ${ }^{4}$ Likewise, environmental disputes

\footnotetext{
Jimly Ashiddiqie, Green Constitution, http:/www.jimlyschool.com/read/program/254/greenconstitution, retrieved on 30th of August 2014.

Ibid.

Siti Sundari Rangkuti, Hukum Lingkungan dan Bisnis Hijau, dalam Radian Salman, dkk (ed) Dinamika Perkembangan Hukum Tata Negara dan Hukum Lingkungan, Airlangga University Press, Surabaya, 2008 at 56.

4 Walhi Jatim, Warga Umul Gemulo Perjuangkan Sumber mata Air Hingga ke Jakarta http:/walhijatim.or.id/2014/03/warga-umbul-gemulo-perjuangkan-sumber-mata-air-hingga-kejakarta/ retrieved on lst of September 2014.
} 
have taken the form of cases of the establishment of cement factories in Pati and Rembang, both of which are located in Central Java; cases of gold mining in Banyuwangi Regency, East Java; pollution cases involving waste material in Lakardowo, Mojokerto Regency; cases of forest fires in Sumatra; mining cases in Kalimantan; cases of the establishment of Steam Power Plants (PLTU) in Batang Central Java, Bali and Palu in Central Sulawesi; and cases of sea and river pollution.. The cases of environmental disputes that occur are mostly caused by government or state negligence in supervising and enforcing environmental law. In cases of negligence, the state was then sued by citizens through a citizen law suit.

The first environmental dispute case submitted by a citizen to the government was a case of an environmental dispute in the Jakarta State Administrative Court, Case No. 008/G/1994. This dispute is a state administrative dispute in the environmental field for the issuance of Presidential Decree No. 42 of 1994 concerning Loan Aid originating from the Reforestation Fund to PT. IPTN (object of dispute). This lawsuit was submitted by Walhi, Yayasan Forum Studi Kependudukan dan Lingkungan Hidup, Yayasan Pengembangan Hukum Lingkungan and Yayasan Forum Studi Kependudukan dan Lingkungan Hidup as plaintiffs against the President of the Republic of Indonesia. ${ }^{5}$

In 2019, the Surabaya District Court received a citizen law suit regarding the environment, which was proposed by residents of Sidoarjo Regency and Batu City. The lawsuit was submitted due to negligence carried out by four (4) state agencies, namely the East Java Provincial Government, the Ministry of Environment and Forestry, the Ministry of Public Works and Public Housing, and the Brantas River Regional Office. The government's negligence in this case was a result of government failure to control the disposal of single-use diaper waste (pospak) into the Brantas river. This case is registered with case number 130 / Pdt.G / 2019 / PN.Sby. ${ }^{6}$

The huge number of environmental disputes that use citizen law suit is to be examined through the study of law, especially by using the perspective of the legal system in Indonesia. The practice of citizen lawsuits in Indonesia occur in both the District Court and the State Administrative Court, although it has not been formally regulated yet. This step is taken by citizens as an alternative method to demand the fulfillment of the government's responsibility for a good and healthy environment. The main problem in this study is first, what form of legal regulation is related to citizen lawsuits in environmental cases? Second, what obstacles arise in filing citizen lawsuits?

This research employs a socio-legal research approach. Socio-legal is actually an 'umbrella concept', covering all approaches to law, legal processes, and the legal system. The socio-legal approach is a combination of approaches in the social sciences, including other sciences that are combined with approaches known in law, such as

\footnotetext{
5 A'an Efendi, Penyelesaian Sengketa Lingkungan Melalui Peradilan Tata Usaha Negara, 2013, Volume XVIII No.l, Jurnal Perspektif Fakultas Hukum Universitas Wijaya Kusuma Surabaya at 17.

6 Kompas, Popok Bayi Cemari Brantas, 2 Perempuan Ini Gugat Pemerintah, https://nasional.tempo.co/read/1174641/popok-bayi-cemari-brantas-2-perempuan-ini-gugatpemerintah retrieved on 19th of May 2019.
} 
learning about principles, doctrines and hierarchies of legislation. ${ }^{7}$ The socio-legal approach is an attempt to further explore a problem by not fulfilling the study of related legal norms or doctrines, but also seeing in full context a norm and its application. A combined approach is expected to strengthen the search for truth and exploration of problems that occur. The socio-legal approach is a liberating approach. ${ }^{8}$ The socio-legal approach was chosen to be used in this study to answer the two key questions regarding citizen lawsuits in environmental cases in Indonesia.

\section{BASIC CONCEPT OF ENVIRONMENTAL DISPUTE}

The term environmental dispute is known in the Indonesian legal system. Environmental disputes have existed since the creation of Law No. 4 of 1982 concerning Principal Provisions for Environmental Management, which was later amended by Law No. 23 of 1997 concerning Environmental Management, and is mentioned again in the PPLH Act of 2009. Based on PPLH Law environmental disputes can be divided into three types. ${ }^{9}$ First, administrative environmental dispute. This type of dispute usually arises because public officials issue certain policies. Disputes occur if the policy is deemed to be contrary to the laws and regulations or violates the general principles of good governance. ${ }^{10}$ Second, civil environmental dispute. This type of dispute usually arises because of pollution and environmental damage. The procedure used can be in the form of class action through organizational lawsuits, citizen lawsuits, and government lawsuits (but, in most cases of environmental disputes, government agencies actually become part of the defendant and / or co-defendant). Third, criminal environmental dispute. In this context, criminal sanctions are put forward, by fighting in court between the perpetrators of environmental crimes and the state as represented by the public prosecutor. ${ }^{11}$

The dispute referred to by the author is a contentious dispute ${ }^{12}$ in the practice of a civil suit in a public court, not a dispute in an administrative court or even criminal court. Settlement of environmental disputes as stipulated in UUPPLH Article 84 paragraph (1) can be reached through a court (in court settlement) or out of court (out court settlement). Settlement of environmental disputes through a court can be filed using a lawsuit against the extant law (PMH) (some also refer to the lawsuits against illegal acts) by requesting compensation and/or policy changes for environmental recovery, as is the concept of Article 1365 BW. ${ }^{13}$ The lawsuit may be filed with any of the following

Herlambang P. Wiratraman, Makalah, Penelitian Sosio-Legal dan Konsekuensi Metodologisnya at 1.

Ibid at 2.

9 Abetnego Tarigan, Hukum Lingkungan, dalam Mohammad Yasin dan Herlambang Perdana (ed), Panduan Bantuan Hukum Di Indonesia, YLBH dan Australia Indonesia Partnership for Justice, Jakarta, 2014 at 207.

10 Ibid.

Il Ibid.

12 Contentiosa lawsuits are claims arising from two or more parties in dispute. See M. Yahya Harahap, Hukum Acara Perdata, Sinar Grafika, Jakarta, 2005 at 46.

13 Civil environemtal law according to NSJ Koeman has a function to obtain a compensation as a result of unlawful acts and legal enforcement function. See Takdir Rahmadi, Penegakan Hukum Lingkungan Di 
mechanisms: conventional or regular lawsuit; class action; organizational lawsuit (legal standing organization); and the citizen lawsuit

Conventional or ordinary lawsuits are basically submitted by everyone (natuurlijk persoon) or legal entities (recht persoon) who become victims directly as a result of environmental cases. This mechanism uses the general procedural law. Contrastingly, the class action mechanism is submitted by a group of victims represented by a representative group (class representative), andprocedural law is based on Supreme Court Regulation No. 1 of 2002. Legal standing organization is a claim mechanism for environmental disputes that can be submitted by organizations or NGOs incorporated as legal entities. In their Articles of Association it must be stated that one of the organization's institutional activities is related/engaged in environmental management and protection. The organization's lawsuit does not require the status of a victim in the environmental case. The last mechanism is a citizen lawsuit (citizen lawsuit / actio popularis). The difference in the four claim mechanisms can be seen from the following table:

Table. 1 Comparison of Lawsuits (Ordinary, Class Action, Legal Standing, and CLS) ${ }^{14}$

\begin{tabular}{|c|c|c|c|c|}
\hline & $\begin{array}{l}\text { Ordinary Civil } \\
\text { Lawsuit }\end{array}$ & Class Action & Legal Standing & $\begin{array}{l}\text { Citizen Law } \\
\text { Suit }\end{array}$ \\
\hline Philosophy & Individualistic & $\begin{array}{l}\text { Distrust of } \\
\text { Individualistic }\end{array}$ & $\begin{array}{l}\text { NGOs as } \\
\text { Guardians }\end{array}$ & $\begin{array}{l}\text { Individuals } \\
\text { capable of } \\
\text { representing } \\
\text { the public } \\
\text { interest }\end{array}$ \\
\hline The term & Civil Lawsuit & $\begin{array}{l}\text { group representative } \\
\text { lawsuit }\end{array}$ & NGO Standing & Citizen Lawsuit \\
\hline $\begin{array}{l}\text { Relationship } \\
\text { Interests }\end{array}$ & $\begin{array}{l}\text { Direct Interest } \\
\text { (real \& tangible) }\end{array}$ & $\begin{array}{l}\text { Direct Interest (real } \\
\& \text { tangible) }\end{array}$ & $\begin{array}{l}\text { Does not have } \\
\text { Direct Interest } \\
\text { (real \& } \\
\text { tangible) }\end{array}$ & $\begin{array}{l}\text { Has no Direct } \\
\text { Interest ( real \& } \\
\text { tangible) }\end{array}$ \\
\hline Claims & $\begin{array}{l}\text { Material } \\
\text { compensation } \\
\text { and certain } \\
\text { action }\end{array}$ & $\begin{array}{l}\text { Material } \\
\text { compensation and } \\
\text { certain action }\end{array}$ & $\begin{array}{l}\text { Certain action } \\
\& \text { out of pocket } \\
\text { expenses }\end{array}$ & $\begin{array}{l}\text { Certain actions, } \\
\text { implementation } \\
\text { of legal } \\
\text { obligations }\end{array}$ \\
\hline Subjects & $\begin{array}{l}\text { People who } \\
\text { directly harmed }\end{array}$ & $\begin{array}{l}\text { Class Representatives, } \\
\text { Class Members }\end{array}$ & $\begin{array}{l}\text { Organizations } \\
\text { that fulfill the } \\
\text { requirements }\end{array}$ & Citizens \\
\hline Notifications & Not required & $\begin{array}{l}\text { Notification from } \\
\text { Class Representative to } \\
\text { Class Member }\end{array}$ & Not required & $\begin{array}{l}\text { Notification } \\
\text { from Plaintiff to } \\
\text { Defendant }\end{array}$ \\
\hline
\end{tabular}

Indonesia : Hambatan dan Beberapa Saran Pembaruan, in Radian Salman, et. Dinamika Perkembangan Hukum Tata Negara dan Hukum Lingkungan, Airlangga (Surabaya: 2008, University Press) at 342.

14 Dhabi K. Gumarya, Hukum Lingkungan, dalam Patra M. Zen (ed), Panduan Bantuan Hukum di Indonesia, Aussaid, YLBHI, PSHK, IALDF, Jakarta, 2006 at 382. 
Of the four mechanisms above, the citizen lawsuit is rarely used in the practice of environmental disputes.

\section{CITIZEN LAWSUIT IN ENVIRONMENTAL CASES}

Citizen lawsuit is a lawsuit against the state or the government with the plaintiff is a citizen who does not have a causal relationship with losses caused by the state/government. ${ }^{15}$ The first citizen lawsuit in Indonesia was submitted in the case of handling the deportation of migrant workers from Malaysia in Nunukan North Kalimantan in 2003, Case No. 28 / Pdt.G / 2003 / PN. Jkt. Pst, which then gives recognition of citizen lawsuit in Indonesia. According to Dhabi K. Gumayra, ${ }^{16}$ a citizen lawsuit was first filed only against environmental problems. However, in the development of citizen lawsuits, they are no longer only submitted in environmental cases, but in all fields where the state is considered negligent in fulfilling the rights of citizens (including the rights for a good and healthy environment). Basically, citizen lawsuit is the access of every citizen to the whole public interest including the interests of a healthy and good environment, by filing a lawsuit in court to demand that the government enforces the required law to or compensates the public loss that occurred.

Citizen lawsuit is also known as a public lawsuit (actio pupularis). The problem of the public lawsuit (actio pupularis) according to Nieuwenhuis in commenting on the verdict (arrest) on the famous Hoge Raad of the Netherlands which is arrest nieuwe meer (a new problem). ${ }^{17}$ In the United States, this model of citizen lawsuit in the field of environment is defined as the rights granted by law to citizens to sue other people, countries, other parties or a combination of the three to protect the environment. Citizen lawsuits can be submitted if there is a violation of the law or a threat to the environment. ${ }^{18}$ Citizen lawsuit was once submitted by the Wahana Lingkungan Hidup (Walhi) Foundation to PT. Indorayon at the Medan District Court. However, the lawsuit was deemed unacceptable (niet ontvankelijk). ${ }^{19}$ Consequently, Decision 28 / Pdt.G / 2003 / PN. JKT. PST can be used as basis for citizen lawsuit in Indonesia.

In the case of current environmental disputes, citizen lawsuit is one of the mechanisms chosen by several plaintiffs. Based on the author's notes there are four cases that use citizen lawsuit within the last five years in cases of environmental disputes: (1) Case No. 66 / Pdt.G / 2014 / PN. Mjk., submitted by a resident of Mojokerto Regency to the Regent of Mojokerto and the Head of the Environmental Agency of Mojokerto

15 Asfinawati, Advokasi, dalam Mohammad Yasin dan Herlambang Perdana (ed), supra note 9 at 583.

16 Abdul Fatah, Gugatan Warga Negara (Citizen Law suit) Sebagai Mekanisme Pemenuhan Hak Asasi Manusia dan Hak Konstitusional Warga Negara, 2013, Volume 28 No. 3, Jurnal Ilmu Hukum Fakultas Hukum Universitas Airlangga, Yuridika.

17 Andi Hamzah, Penegakan Hukum Lingkungan, Sinar Grafika, Jakarta, 2005, page. 101

18 Hukumonline, Pro-Kontra Citizen law Suit, Belajar dari Kasus Nunukan, http:/www.hukumonline.com/berita/baca/hol8003/prokontra-citizen-law-suit-belajar-dari-kasusnunukan, retrieved on 7 th of October 2014.

19 Ibid. 
Regency, ${ }^{20}$ (2) Case No. 92 / Pdt.G / 2014 / PN. Gsk., ${ }^{21}$ submitted by a Gresik resident to the Gresik Regent, East Java Governor, Minister of Public Works and Public Housing, and Head of the Brantas River Regional Office; (3) Case No. 200 / Pdt.G / 2019 / PN. Sby., ${ }^{22}$ submitted by Surabaya residents to Surabaya Mayor, Head of Surabaya Land Office and Surabaya DPRD Chairperson: and (4) Case No. 130 / Pdt.G / 2019 / PN. Sby., ${ }^{23}$ filed by two people from Batu and Sidoarjo against the Minister of Environment, the Governor of East Java, the Minister of Public Works and Public Housing, and the Head of the Brantas River Regional Office. In detail, the four cases above are summarized in the table below:

Table 2. Claims of Citizen Law Suit / Actio Popularis Regarding the Environment

\begin{tabular}{|c|c|c|}
\hline Parties to the & $\begin{array}{c}\text { Lawsuit / } \\
\text { Mechanism of }\end{array}$ & Petitum \\
\hline $\begin{array}{l}\text { Case No. 66 / Pdt.G / } \\
\text { 2014 / PN. Mjk } \\
\text { Zunianto (Plaintiff) } \\
\text { Opponent: } \\
\text { 1. Local Government } \\
\text { of Mojokerto } \\
\text { Regency } \\
\text { (Defendant I) } \\
\text { 2. Environmental } \\
\text { Agency of } \\
\text { Mojokerto Regency } \\
\text { (Defendant II) }\end{array}$ & $\begin{array}{l}\text { PMH /Citizen } \\
\text { Lawsuit } \\
\text { Mojokerto } \\
\text { District Court }\end{array}$ & $\begin{array}{l}\text { a. Asked the Regent and BLH to immediately } \\
\text { revoke the IPLC permit of PT. MEGAH } \\
\text { SURYA ERATAMA (Article } 76 \text { paragraph } \\
2 \text { of Law Number } 32 \text { of 2009) because it is } \\
\text { clearly proven to carry out pollution and } \\
\text { dispose of waste above the quality } \\
\text { standard. } \\
\text { b. Closing the OUTLET of PT. MEGAH } \\
\text { SURYA ERATAMA (Article } 80 \text { paragraph } \\
1 \text { letter C of Law Number } 32 \text { of 2009) } \\
\text { because if it is left unchecked, I am worried } \\
\text { that the impact of pollution will be more } \\
\text { widespread and could endanger the } \\
\text { creatures living in it both biota and fish } \\
\text { and I am worried that it will affect quality } \\
\text { water in the well of the residents. } \\
\text { c. Encouraging PT. MEGAH SURYA } \\
\text { ERATAMA immediately carried out } \\
\text { recovery / prevention of pollution to the } \\
\text { ecosystem of Kali Porong so that it was } \\
\text { free from murky colors and foam. (Article } \\
53,54,87 \text { of Law Number } 32 \text { Year 2009). }\end{array}$ \\
\hline $\begin{array}{l}\text { Case No. } 92 \text { / Pdt.G / } \\
2014 \text { / PN. Gsk } \\
\text { Rulli Mustika Adya SH } \\
\text { Opponents: }\end{array}$ & $\begin{array}{l}\text { PMH /Citizen } \\
\text { Lawsuit Grants } \\
\text { Gresik District } \\
\text { Court }\end{array}$ & $\begin{array}{l}\text { a. Grant the plaintiff's entire claim; } \\
\text { b. Sentenced and ordered Defendant I and the } \\
\text { defendants to immediately coordinate the } \\
\text { demolition City Nine store and } \\
\text { warehousing buildings carried out by the }\end{array}$ \\
\hline
\end{tabular}

20 SIPP Mojokerto District Court, http://www.sipp.pn-mojokerto.go.id/, retrieved on 17th of December 2014.

${ }_{21}$ SIPP Gresik District Court, http://www.sipp.pn-gresik.go.id/, retrieved on 17th of December 2014.

22 SIPP Surabaya District Court, https://sipp.pn-surabayakota.go.id/ retrieved on 19th of May 2019.

23 Ibid. 
1. Government of Indonesia

2. Ministry of Public Works,

3. Center for Brantas River Region

4. East Java Provincial Government developer PT. Graha Mitra Niaga Investindo in Gading Village Desa Cangkir Kec. Driyorejo Kab. Gresik East Java;

c. Punish and order the defendants to coordinate immediately to make an information system related to the prohibition of building on river boundary land which serves as a protection for the preservation of river functions to anticipate floods and landslides;

d. Punish and order the defendants to coordinate according to the duties of their authority and responsibility to make preventive efforts towards the transfer of the function of river stripping in Surabaya by providing information by installing information boards and giving written warnings to the perpetrators of violations on the use of the river in Surabaya.

e. Punish and order the defendants to coordinate and determine the priority of the demarcation of river border locations on river segments that have environmental damage due to land use that are not in accordance with government regulations and cause environmental disturbances, congestion, flooding and river pollution in the area, among others: a. kab gresik: desa cangkir and desa bambe b.kab sidoarjo: kelurahan along tawangsari and pereng c Surabaya: Kelurahan Warung Gunung, Karang Pilah, and Kebonsari

f. Punish and order the defendants to immediately conduct a study with the relevant agencies, including the government of gresik, Regional Irrigation Service. East Java province and the environmental agency of East Java province to make adjustments related to the construction of shops and warehousing PT.Graha Mitra Niaga Investindo in the border of Surabaya River.

g. Punish and order the defendants to coordinate to collaborate with the provincial government and the central 


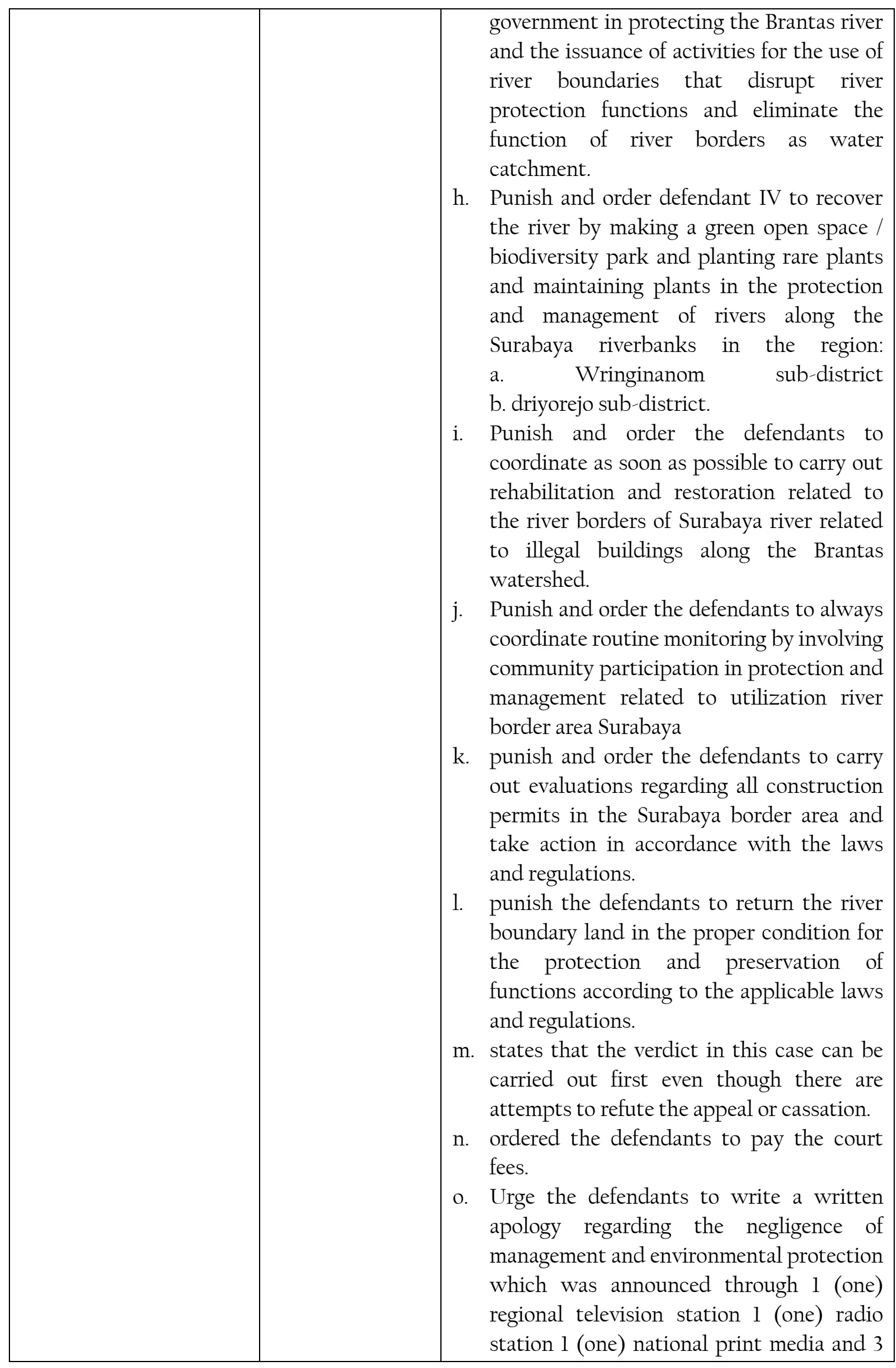




\begin{tabular}{|c|c|c|}
\hline & & $\begin{array}{l}\text { (three) regional print media for two days } \\
\text { consecutively the contents read as follows: } \\
\text { "we the minister of public works, the } \\
\text { governor of east java, the regent of gresik, } \\
\text { and the brantas river region apologized } \\
\text { profusely to all the residents of kab gresik } \\
\text { for acts that were against the law that we } \\
\text { did related to negligence and or negligence } \\
\text { on the construction of shop houses and a } \\
\text { warehouse above the Surabaya river border } \\
\text { area which is located in the village, } \\
\text { presumably the remorse for this unlawful } \\
\text { act is the starting point to show respect for } \\
\text { the protection and discovery of human } \\
\text { rights and protection and circumvention of } \\
\text { the environment ". } \\
\text { p. states that the verdict in this case can be } \\
\text { carried out first even though there are } \\
\text { attempts to refute the appeal or cassation. }\end{array}$ \\
\hline $\begin{array}{l}\text { Case No. } 200 \text { / Pdt.G / } \\
\text { 2019 / PN .Sby } \\
\text { Hermanto } \\
\text { Opponent: } \\
\text { 1. Mayor of Surabaya } \\
\text { 2. City Council of } \\
\text { Surabaya } \\
\text { 3. Head of Land Office I }\end{array}$ & $\begin{array}{l}\text { PMH /Citizen Law } \\
\text { Suit } \\
\text { Surabaya District } \\
\text { Court }\end{array}$ & $\begin{array}{l}\text { Under the Provision } \\
\text { 1. Granting the whole Plaintiff's } \\
\text { Provision Claims; } \\
\text { 2. Declare legal and valuable seizure } \\
\text { guarantees for the Object of Sepat } \\
\text { Reservoir Case; } \\
\text { Case of Lawsuit } \\
\text { 1. Grant the whole Plaintiff's lawsuit; } \\
\text { 2. Stating THE DEFENDANT been } \\
\text { negligent in protecting (to protect), } \\
\text { respect (to respect) and meet (to fulfil) the } \\
\text { rights of PLAINTIFF as citizens and } \\
\text { other citizens, namely the right to a } \\
\text { good and healthy environment, the } \\
\text { right to work and rights for a safe, } \\
\text { peaceful and prosperous life; } \\
\text { Declare the actions of the ACCUSED } \\
\text { who do not provide protection for the } \\
\text { right to a good and healthy } \\
\text { environment and the rights to the } \\
\text { economy, social and culture are against } \\
\text { the law; } \\
\text { 2. Sentencing ACCUSED I and } \\
\text { ACCUSED II to return the Case Object } \\
\text { in its original form; } \\
\text { 3rder Defendant I and/or Defendant II } \\
\text { to issue a policy that is to maintain and }\end{array}$ \\
\hline
\end{tabular}




\begin{tabular}{|c|c|c|}
\hline & & $\begin{array}{l}\text { conserve objects of dispute in which } \\
\text { there is protection for a good and } \\
\text { proper environment: } \\
\text { 1. } \\
\text { Publish and / or make changes } \\
\text { to the Regional Regulation of } \\
\text { Surabaya concerning regional } \\
\text { spatial plans (RTRW) by } \\
\text { entering object of dispute as a } \\
\text { protected area; } \\
\text { 2. Issue the Regional Regulation } \\
\text { of the City of Surabaya } \\
\text { concerning the Recognition } \\
\text { and Protection of the } \\
\text { traditional, customary and } \\
\text { Cultural areas in the Surabaya } \\
\text { city by including Sepat } \\
\text { Shamanism and the Disputed } \\
\text { Objects as a protected area of } \\
\text { traditional, customary and } \\
\text { Cultural territory; } \\
\text { The Defendant I issued a } \\
\text { Surabaya Mayor Regulation } \\
\text { concerning Determination of } \\
\text { the Object of the dispute as } \\
\text { part of a Protected Area; } \\
\text { The Defendant I issued a } \\
\text { pay all costs arising from this case; } \\
\text { Surabaya Mayor Regulation } \\
\text { concerning the Determination } \\
\text { of Sepat Shamanism and the } \\
\text { Disputed Object as a protected } \\
\text { area of the traditional, } \\
\text { customary and cultural } \\
\text { territory; }\end{array}$ \\
\hline $\begin{array}{l}\text { Case No. } \\
\text { 130 / Pdt.G / } 2019 \text { / } \\
\text { PN.Sby } \\
\text { Mega Mayang and Riska } \\
\text { Darmawanti } \\
\text { Opponent: }\end{array}$ & $\begin{array}{l}\text { PMH /Citizen Law } \\
\text { Suit } \\
\text { Surabaya }\end{array}$ & $\begin{array}{l}\text { 1. Receives and grants the entire claim of the } \\
\text { plaintiffs } \\
\text { 2. Stating that the defendants have } \\
\text { committed acts against the Law } \\
\text { 3. Ordered the ACCUSED to apologize to the } \\
\text { Brantas river and East Java citizens who } \\
\text { were published in national and electronic }\end{array}$ \\
\hline
\end{tabular}


1. East Java Governor

2. Minister of Environment

3. Minister of Public Works and Public Housing

4. Balai Besar Wilayah Sungai Brantas print media respectively 5 media. In this case the format and contents are determined by plaintiff.

4. Ordered ACCUSED to carry out the installation of 2,020 CCTV in the river bridge of the Brantas watershed area to improve the SUPERVISION function of POSPAK dumpers.

5. Ordered the ACCUSED people to conduct an independent examination of all DLH in East Java Province, both the provincial DLH and the district/city DLH which involved elements of society, academics, environmental consultants and NGOs in the field of waste management and the environment.

6. Ordered the ACCUSED PARA to build a 2020 Free Post River Monument (POSPAK) in the upstream, middle and downstream areas of the Brantas watershed with images and measures in determining the involvement of the community.

7. Ordered the defendant to issue a warning against the people of East Java, especially the people who lived in the Brantas watershed area which contained one of their statements, namely BRANTAS, NOT A PLACE TO WASTE POPTS.

8. Ordered the defendant to take legal action in the form of an administrative sanction for the community based on the CCTV installed and the POSPAK manufacturer who did not withdraw the product when POSPAK was cleared on the river.

9. Ordered the defendant to establish an SOP policy related to POSPAK waste handling in East Java.

10. Ordered the defendant to clean up POSPAK garbage scattered in the environmental media, especially the Brantas watershed in East Java.

11. Ordered the defendant to carry out a campaign and education on the use of clodi to PKK organizations in East Java especially the people inhabiting the 


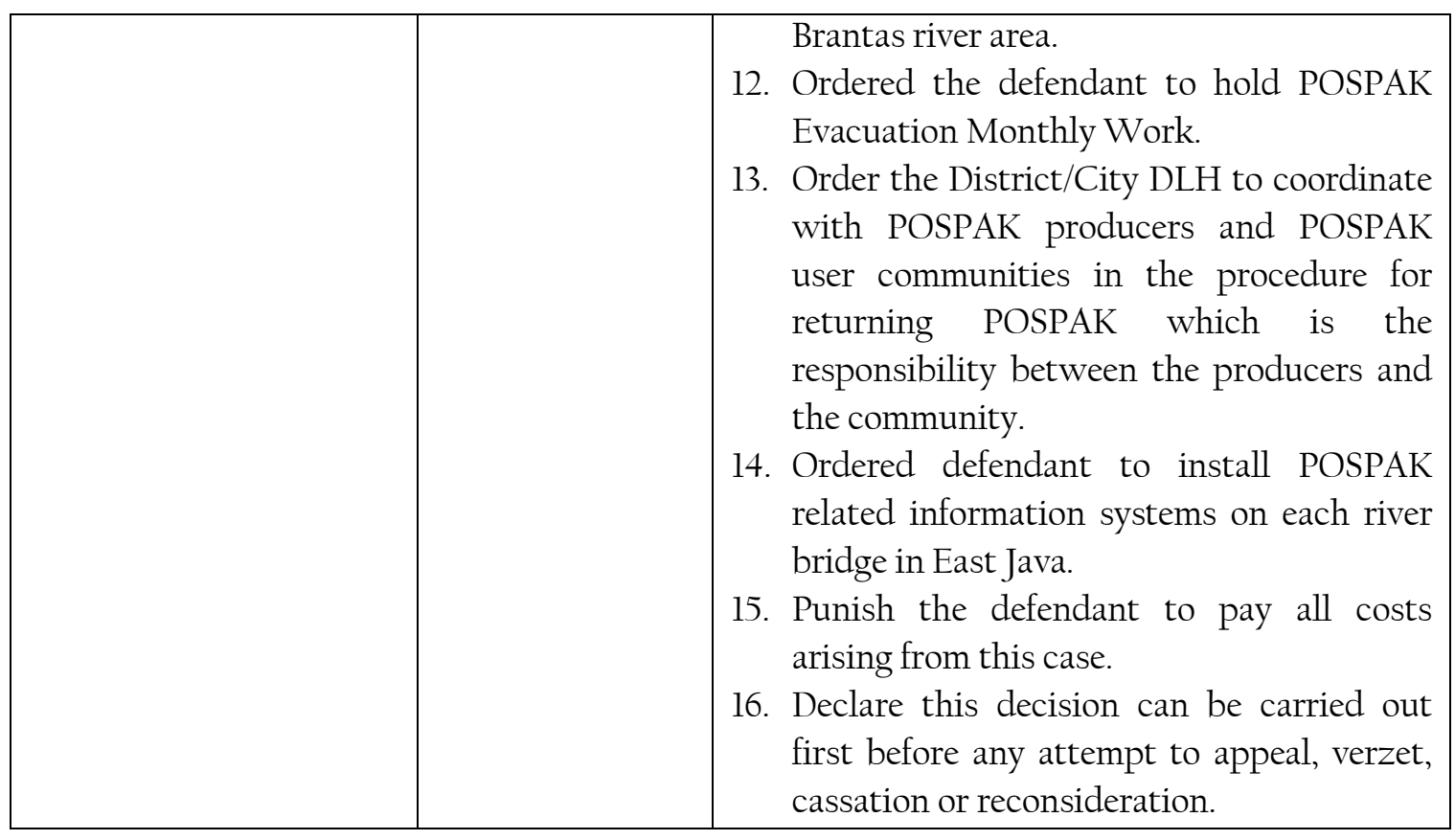

From the four cases above, valuable information can be obtained. The four lawsuits were filed without an adequate legal basis regarding citizen lawsuit. This was possible because there are no regulations that specifically apply to citizen lawsuits, therefore in the environmental cases there are no arrangements related to the citizen lawsuits. The plaintiffs deliberately utilize the legal principle of ius curia novit (the judge must not reject the case) as the door to file this lawsuit. Despite the absence of legal basis, the cases above are proof that a citizen's lawsuit has become the preferred alternative for people or groups who notably are a citizen (citizen) to dispute the environmental cases due to state negligence. This is an opportunity that has been built for national legal reform. In the Indonesian legal system, a citizen lawsuit is not formally known; therefore, in the Indonesian judicial system there is no right to citizen lawsuit.

One interesting thing to study through a socio-legal lens is filing processes in environmental cases. Filing a lawsuit in some environmental cases is accomplished by educated society on behalf of citizens at large with support from multiple parties. Often, this lawsuit is driven by environmental activists, academics and NGOs. Starting with case discussions involving many parties, academic studies, case degrees, and the process of annotations from public lawyers, new submissions and registrations were conducted at the Court. For now, the filing of a citizen lawsuit (actio popularization) in Indonesia is included in the field of environmental disputes, and four of the cases above, are based or guided by the decision of the Central Jakarta District Court No. 28 / Pdt.G / 2003 / PN. Jkt. Pst, because there are no legal rules that regulate the procedure of proceedings by using a citizen lawsuit in Indonesia. This has become an obstacle in the enforcement of environmental law, especially civil disputes.

However, currently the citizen lawsuit for environmental cases receives legality and recognition, as well as guarantees from the Supreme Court of the Republic of Indonesia. 
This can be found in the Decree of the Chief of the Supreme Court of the Republic of Indonesia No. 36 / KMA / SK / II / 2013 concerning the Application of Guidelines for Handling Environmental Cases. This basis can be the guarantee for citizens to sue the government/state for their negligence in obtaining citizens' rights for a healthy and good environment.

In terms of legislation, citizen lawsuits in environmental cases should be regulatory (regeling) rather than deciding or provisional. Then it should be the Republic of Indonesia Supreme Court Regulation (Perma). However, Decree of the Chief Justice of the Supreme Court No. 36 / KMA / SK / II / 2013 has contributed to filling the legal vacuum created by regulations over citizen lawsuits or the lack thereof. In that Decree, the Chief of the Supreme Court recognized citizen lawsuits as one of the legal mechanisms to handle environmental problems. There is no longer sufficient reason for the judge to make a decision by saying that the lawsuit is unacceptable due to the absence of guideline as in the case of Walhi's lawsuit against PT. Indorayon.

Citizen lawsuits (actio popularis) cases of environmental disputes can be submitted at the General Court based on:

a. Decision of the Central Jakarta District Court No. 28 / Pdt.G / 2003 / PN. Jkt. Pst.

The Panel of Judges of the Central Jakarta District Court issued a Decision in the Case of Migrant Workers' Citizen Law Suit lawsuit number No.28 / Pdt.G / 2003 / PN.Jkt. Pusat by the Panel of Judges Andi Samsam Nganro, SH. (Chairperson of the Panel of Judges H. Iskandar Tjake, SH and Mrs. Effendy Lotulung, SH (members of the assembly) who stated in their considerations stated:

1. Referring to the juridical, philosophical and moral foundation in the framework of legal systems and doctrines, the Panel of Judges held that citizen lawsuits, the right to file a lawsuit for the citizens in the name of public interest is not necessarily that of the person who experienced the loss and does not require a special authorization letter from members of the community are represented.

2. Realizing every citizen has the right to defend the public interest, thus every citizen on behalf of the public interest can sue the state or the government or anyone who commits an act against the law (PMH) that is clearly detrimental to the public interest and welfare vast (probono publico), this is in accordance with human rights regarding access to justice, namely access to justice if the state is silent or does not take any action for the benefit of its citizens;

This decision greatly contributed to the recognition of citizen law suits in Indonesia, especially in environmental disputes.

b. Decree of the Chief of the Supreme Court of the Republic of Indonesia No. 36 / KMA / SK / II / 2013 concerning Application of Guidelines for Handling Environmental Cases in Chapter IV Guidelines for Handling Environmental Civil Cases in which citizen lawsuit (actio popularis). 
Citizen lawsuit (actio popularis) in cases of environmental disputes filed in general court with the basic state negligence concerning environmental problems, omissions can be categorized as acts against the law so that the type of lawsuit filed is lawsuit for violating the law (PMH). In a citizen lawsuit (actio popularis), the government acts as the defendant and citizens act as the plaintiff. Citizens here are proven by the existence of an Identity Card (KTP) that contains the Population Registration Number, Passport, and / or proof of paying tax (taxpayer). The procedure for filing a citizen claim is as a civil procedure law that generally distinguishes the standing of the plaintiff and the notification from the plaintiff to the defendant.

Table. 3 Identification Class Action

\begin{tabular}{|l|l|}
\hline Plaintiff & $\begin{array}{l}\text { Citizen, so that those who have the legal standing to file a citizen } \\
\text { lawsuit (actio popularis) are proven by KTP / Passport / Proof as a } \\
\text { Taxpayer. }\end{array}$ \\
\hline Defendant & Government / State \\
\hline Petitum & $\begin{array}{l}\text { The existence of a policy change and apology, is not known for } \\
\text { requesting material compensation. }\end{array}$ \\
\hline Characteristic & existence of the notification and environmentally certified judge \\
\hline
\end{tabular}

In filing a citizen lawsuit, there is specificity in petitum, which also applies to an environmental dispute. Petition for the decision of a citizen law suit must: ${ }^{24}$ (1) not ask for material compensation, because citizens who sue are not groups that are materially disadvantaged and have the same loss and similarity in legal facts as the class action; (2) contain a request that the state issue a general regulation policy so that illegal acts in the form of negligence in fulfilling the rights of citizens in the future will not occur or repeat itself; (3) not be a cancellation of the decision of state officials (administrative decision) which is concrete, individual and final because it is under the authority of the State Administrative Court (PTUN); (4) not be a cancellation of an enactment law (UU) because it is the authority of the Constitutional Court (MK). In addition, citizen law suits may not ask for cancellation of laws and regulations under the law because this is the authority of the Supreme Court (MA) based on Judicial Review.

By observing several cases or cases of environmental disputes using the mechanism of citizen law suits above using socio legal approach, it is interesting to find that the lawsuits do not have a solid basis. This is due to the absence of legal institutions in the form of regulations that regulate the submission of citizen lawsuits, especially environmental disputes.

Based on the facts of the Plaintiffs, there are still many reports that the plaintiff's lawsuit is not in accordance with the Chief Justice of the Indonesian Supreme Court No. 36 / KMA / SK / II / 2013 concerning the Implementation of Guidelines for Handling Environmental Cases for several reasons. For example, there are still requests for

${ }^{24}$ The Supreme Court of the Republic of Indonesia, The Supreme Court Report in 2009. 
material compensation and do not ask for new policies, and those that are petitioned for are technical. Accordingly, many citizen lawsuits were rejected by judges and usually based on:

1. Article $28 \mathrm{H}$ paragraph (1) of the 1945 Constitution concerning the basic rights of every Indonesian citizen to obtain a good and healthy environment.

2. Law No. 39 of 1999 concerning Human Rights.

3. Law No. 11 of 2005 concerning Ratification of the Economic, Social and Cultural Covenant.

4. Article 65 paragraph (1) of the PPLH Law which reads "everyone has the right to a good and healthy environment as part of human rights."

5. Article 65 paragraph (2) of the PPLH Law which reads "everyone has the right to environmental education, access to information, access to participation, and access to justice, in fulfilling the right to a good and healthy environment."

6. Article 65 paragraph (3) of the PPLH Law which reads "everyone has the right to submit proposals and / or objections to the business plan and / or activities that are expected to have an impact on the environment."

7. Article 65 paragraph (4) of the PPLH Law which says "everyone has the right to play a role in the protection and management of the environment in accordance with the laws and regulations."

8. Article 65 paragraph (5) of the PPLH Law reads "everyone has the right to make a complaint due to alleged environmental pollution and / or destruction."

9. Article 70 paragraph (1) and paragraph (2) of the PPLH Law concerning the role of the community.

10. Article 80 paragraph (2) of the PPLH Law which reads "the imposition of government coercion can be imposed without prior reprimand if the violation committed raises: a. serious threat to humans and the environment, b. greater and wider impact if not stopped immediately. C. greater losses to the environment if pollution is not immediately stopped."

11. Article 91 paragraph (1) of the PPLH Law concerning community lawsuit.

12. Law No. 48 of 2009 concerning Judicial Power.

13. Decision of the Central Jakarta District Court No. 28 / Pdt.G / 2003 / PN. Jkt. Pst.

14. Decree of the Chief of the Supreme Court of the Republic of Indonesia No. 36 / KMA / SK / II / 2013 concerning the Application of Guidelines for Handling Environmental Cases.

Based on the results of direct observation of the practice of a citizen lawsuit in East Java in the four cases above, it was found that not all cases were subject to the Decree of the Chair of the Supreme Court of the Republic of Indonesia issued Decree No. 134 / KMA / SK / IX / 2011 concerning Judge Certification Living environment.

That the development of environmental law in Indonesia is very fast. Since the enactment and promulgation of the PPLH Law in 2009, in 2011 on September 5, 2011 the Chair of the Supreme Court of the Republic of Indonesia has issued Decree No. 134 / 
KMA / SK / IX / 2011 concerning Certification of Environmental Judges. Decree 134 / KMA / SK / IX / 2011 regulates the following matters:

a. Authority of environmental certified judges;

b. Selection stages;

c. Appointment and placement;

d. Monitoring and evaluation;

e. Incentives and disincentives; and

f. Funding

The Decree on Environmental Judge Certification aims to improve the effectiveness of environmental law enforcement. Besides that, the Decree basically becomes the norm that judges who can handle cases of environmental disputes both administrative in the State Administrative Court, Civil and Criminal Disputes in the General Court are judges who have passed environmental judge certification. The aforementioned factors became a guideline for judges who can handle environmental disputes that are disputed with a citizen lawsuit (actio popularis), who are those judges who have passed the certification of environmental judges. Such cases cannot only be handled by judges whose competence is still common. So that citizens who submit citizen lawsuits (actio popularis) cases of environmental disputes when registering a lawsuit can ask the judge who passed the environmental certification.

However, not all cases of environmental disputes, especially with citizen lawsuit, involve case judges who are already environmentally certified, especially in the case above. If in the court concerned there are no environmental certified judges, then it must be conducted terracing from other courts with the permission of the Chair of the High Court as stipulated in Decree No. 134 / KMA / SK / IX / 2011 concerning Certification of Environmental Judges. This was not done by the Chairmen of the District Courts. Based on the facts of the observations made by the author on fourenvironmental cases using the citizen lawsuit mechanism, it is found that the court leader is not obedient to the Supreme Court Chief Decree No. 037 / KMA / SK / III / 2015 dated 20 March 2015 Juncto Circular Letter of the Supreme Court No. 2 Year 2015 dated 3 July 2015 regarding special environmental numbering cases.

The Supreme Court of the Republic of Indonesia (MA) has issued special numbering rules for environmental cases in order to facilitate the identification and inventory of environmental cases. This rule is stated in KMA Decree No. 037 / KMA / SK / III / 2015 dated March 20, 2015 jo SEMA No. 2 Year 2015 dated July 3, 2015. This rule applies to criminal, civil, and administrative cases for all levels of judicial review. For example, civil cases: 00 / Pdt.G / LH / year / district court, 00 / Pdt / LH / year / high court, $00 \mathrm{~K}$ / Pdt.Sus-LH / year, $00 \mathrm{PK}$ / Pdt.Sus-LH / year. However, none of the four cases above are subject to the Chief Justice's Decree. So that the community's right to know that the case is an environmental case has been violated by the court leaders where the four cases were tried. 


\section{OBSTACLES FOR THE ENFORCEMENT OF CITIZEN LAWSUIT IN THE ENVIRONMENTAL CASES}

Citizen lawsuits (actio popularis) in the case of environmental disputes can be filed using several reasons including the guarantee of claims by members of the community as stipulated in Article 91 paragraph (1) of the PPLH Law. However, in practice there are several obstacles so that the claim mechanism has not been effective. First obstacles is the absence of legal rules that specifically regulate citizen lawsuits (actio popularis). The main problem with this citizen lawsuit is that there are no national laws that regulate it specifically and in detail. The fact that Indonesia does not yet have the legal tradition of citizen lawsuits make it an obstacle in the enforcement of environmental law. Citizen lawsuits are widely known and applied in countries that use a common law system.

The second obstacle is the lack of understanding of law enforcement officials (especially judges) regarding citizen lawsuit. This obstacle often arises in the trial of environmental disputes brought about by citizen lawsuits due to law enforcement officers' weak understanding of citizen lawsuits. Judges often still equate citizen lawsuits with ordinary or conventional lawsuits. This has happened in case No. 92 / Pdt.G / 2014 / PN. Gsk. In this case the judge argued that the lawsuit was not due to the inclusion of the corporation, in this case a developer. Whereas clearly in the concept of citizen law suit as a Defendant is the State or the Government.

The final obstacle is the lack of environmentally certified judges in Indonesia, especially at a regional level. This is compounded by the actions of several district court leaders who did not report the matter to the head of the High Court.

\section{CONCLUSION}

The citizen lawsuit in environmental disputes is not regulated in legislation. However, in practice, especially in East Java, the submission of citizen lawsuits in environmental cases is guided by the PPLH Law, especially Article 91 paragraph (1) and Decree of the Chief of the Supreme Court of the Republic of Indonesia No. 36 / KMA / SK / II / 2013 concerning the Implementation of Guidelines for Handling Environmental Cases in Chapter IV Guidelines for Handling Environmental Civil Cases where citizen lawsuit is also based on the Decision of the Central Jakarta District Court No. 28 / Pdt.G / 2003 / PN. Jkt. Pst. Although there has not been an adequate arrangement, this citizen lawsuit becomes an alternative enforcement of environmental law in Indonesia. Three obstacles complicate the use of citizen lawsuits in environmental cases: (1) the absence of a legal regulation that specifically regulates citizen lawsuit, especially the mechanism of referencing; (2) lack of understanding of law enforcement officials (especially judges) regarding citizen lawsuits (actio popularis). (3) lack of environmental-certified judges in Indonesia, especially at regional levels. From the conclusions of this analysis, it is both clear and urgent that the state swiftly shape or draft a Law on Citizen Lawsuits. 


\section{REFERENCES}

Efendi, A'an, Penyelesaian Sengketa Lingkungan Melalui Peradilan Tata Usaha Negara, 2013, Volume XVIII No.1, Jurnal Perspektif Fakultas Hukum Universitas Wijaya Kusuma Surabaya.

Fatah, Abdul, Gugatan Warga Negara (Citizen Lawsuit) Sebagai Mekanisme Pemenuhan Hak Asasi Manusia dan Hak Konstitusional Warga Negara, 2013, Volume 28 No.

3, Jurnal Ilmu Hukum Fakultas Hukum Universitas Airlangga, Yuridika.

Hamzah, Andi Hamzah, Penegakan Hukum Lingkungan, Sinar Grafika, Jakarta, 2005.

Harahap, M. Yahya, Hukum Acara Perdata, Sinar Grafika, Jakarta, 2005.

Herlambang P. Wiratraman, Makalah, Penelitian Sosio-Legal dan Konsekuensi Metodologisnya. Hukumonline, Pro-kontra Citizen law Suit, Belajar dari Kasus Nunukan, http://www.hukumonline.com/berita/baca/hol8003/prokontra-citizen-law-suitbelajar-dari-kasus-nunukan, retrieved on 7th of October 2014.

Jimly Asshiddiqie, Green Constitution, http://www.jimlyschool.com/read/program/ 254/green-constitution, retrieved on 30th of August 2014

Kompas, Popok Bayi Cemari Brantas, 2 Perempuan ini Gugat Pemerintah, https://nasional.tempo.co/read/1174641/popok-bayi-cemari-brantas-2-perempuan-inigugat-pemerintah retrieved on 19th of May 2019.

Patra M. Zen (ed), Panduan Bantuan Hukum di Indonesia, Aussaid, YLBHI, PSHK, IALDF, Jakarta, 2006.

Salman, Radian dkk (ed) Dinamika Perkembangan Hukum Tata Negara dan Hukum Lingkungan, Airlangga University Press, Surabaya, 2008.

SIPPN Mojokerto, http://www.sipp.pn-mojokerto.go.id/, retrieved on 17th of December 2014

SIPP Gresik District Court, http://www.sipp.pn-gresik.go.id/, retrieved on 17th of December 2014

SIPP Surabaya District Court, http://www.sipp.pn-surabaya.go.id/, retrieved on 19th of May 2019

The Supreme Court of the Republic of Indonesia, The Supreme Court Report in 2009.

Yasin, Mohammad dan Herlambang Perdana (ed), Panduan Bantuan Hukum Di Indonesia, YLBH dan Australia Indonesia Partnership for Justice, Jakarta, 2014.Zen, Patra M. (ed), Panduan Bantuan Hukum di Indonesia, Aussaid, YLBHI, PSHK, IALDF, Jakarta, 2006.

Walhi Jawa Timur, Warga Umbbul Gemulo Perjuangkan Sumber Mata Air Hingga ke Jakarta, http://www.walhijatim.or.id/2014/03/warga-umbul-gemulo-perjuangkan -sumber-mata-air-hingga-ke-jakarta/, retrieved on lst of September 2014. 
308 Citizen Lawsuit in Environmental Cases

This page is intentionally left blank 